\title{
Genotypic variations in root traits of wheat varieties at phytomer level
}

\author{
A. H. K. Robin*, M. J. Uddin, S. Afrin and P. R. Paul \\ Department of Genetics and Plant Breeding, Bangladesh Agricultural University, Mymensingh-2202, \\ Bangladesh, *E-mail: gpb21bau@bau.edu.bd
}

\begin{abstract}
The aims of this study were to investigate genotypic variations in root traits at phytomer level of wheat varieties and for recommending a few root traits as selection parameters in future breeding programs. Two separate experiments were conducted to measure their root traits for hydroponically grown wheat plants. In Experiment 1, main axis length, root hair density and diameter differed from phytomer to phytomer at 60 days after sowing for two varieties, Shotabdi and Sonalika. Density of first order laterals at their axis of origin, dry weights of roots and shoots and root:shoot ratio varied significantly among 8 varieties. In Experiment 2, number of root bearing phytomer, total number of adventitious roots, main axis length at root bearing phytomer 1 and 2 (youngest roots were the reference point and numbered as phytomer 1), length of first order laterals at phytomer 3, root hair density and dry weights of roots and shoots were significantly different among varieties. PC1 (principal component 1) resulted in significant variation among varieties for number of live leaves, new roots appeared, number of root bearing phytomer, total number of adventitious roots, root dry weight and shoot dry weight. PC2 yielded significant difference among varieties for live leaves, main axes length at phytomer $1 \& 2$, number of new roots, root hair density and diameter. Selection of varieties based on main axes length at the youngest phytomer \& root hair density per unit surface area along with dry weights of roots and shoots could be recommended for future breeding program as these four parameters consistently resulted in significant variation among varieties.
\end{abstract}

Keywords: Wheat, Phytomer, Root hairs, Lateral roots

\section{Introduction}

Root architecture plays an important role in agricultural productivity by modifying the efficiency of nutrient uptake of the plants from the soil (Lynch, 1995). It is reported previously that some root traits are directly related to grain yield of wheat, e.g., diameter of the roots, are directly related to harvest index and biomass at maturity (Richards and Passioura, 1989), seminal root number is strongly related to grain mass (Bengough et al., 2006) and shallow \& deep root weight and root biomass are positively correlated with grain yield (Ehdaie et al., 2012). There is widespread evidence that root architecture and different root characteristics of many crop species varies among genotypes (Crush et al., 2007; Hebbar et al., 2014; O'Toole and Bland, 1987; Whalley et al., 2013). In a few quite recent studies the importance of studying root architectural traits has been emphasized for adaptation of the crop varieties to various abiotic stress conditions. O'Toole and Bland (1987) described the significance of genotypic variation for adaptation to diverse environments and also in different edaphic niches in agriculture. Manschadi et al. (2006) examined root system characteristics of two wheat genotypes contrasting in tolerance to water limitation and assessed the functional implications on adaptation to water-limited environments and reported that drought-tolerant wheat had a compact root system, while the standard wheat variety had a more uniform rooting pattern and greater root length at depth. Manschadi et al. (2008) evaluated the genotypic variability exists among 30 wheat genotypes based on root system architecture quantified through fractal analysis for drought tolerance and seminal root characteristics. In their study, genotypic variations existed among wheat genotypes for growth angle and number of seminal roots at the seedling stage. Mediterranean wheat varieties had wider growth angle compared to the genotypes adapted to the deep clay soils. Besides, drought stress implications of adventitious root development and root anatomical development towards salinity resistance is also described (Maggio et al., 2001; Saqib et al., 2005). Saqib et al. (2005) reported that under saline-waterlogged conditions the development of adventitious nodal roots and cortical root aerenchyma improves $\mathrm{Na}^{+}$exclusion and salt resistance. 
Previous studies identified a few root traits which are responsive towards different stress factors with variability among genotypes (e.g., Hurd, 1968; Hurd, 1974; Richards and Passioura, 1989). Hurd (1968) reported root growth differences among seven Canadian bread wheat cultivars. In the study of O'Brien (1979) ten wheat genotypes differed in their pattern of root development for the length of main axis at 7 and 8 weeks' of growth. The author reported that length of root main axis was influenced by tiller number and rate of tiller production. In some other previous studies length and number of both nodal and seminal roots, root elongation rate, rooting depth and vertical proportions of root weights were significantly different among genotypes as reviewed by O'Toole and Bland (1987).

Even though root traits directly affects economic yield of wheat and varies among wheat genotypes but majority of the previous studies ignored measuring traits related to lateral roots for varietal screening probably because: i) root measurements are time consuming and laborious, ii) efficient and easy measuring technique is unavailable and also may be, iii) most responsive and 'representative' root traits are yet to identify. On the otherhand, studying root growth and development at the phytomer level and at the phyllochron time-scale is a comparatively newer concept (Robin, 2011; Robin et al., 2010) which can be adopted to identify the variable root traits hydroponically to recommend for the future breeding programs. As far as the literature explored none of the previous studies included traits related to root hairs for assessing genotypic variation. This study therefore, attempts to investigate root growth and development of 13 wheat varieties at the phytomer level to select out the variable root traits, including the traits related to root hairs.

\section{Materials and Methods}

The experiment was conducted at the Department of Genetics and Plant Breeding, Bangladesh Agricultural University. Seeds of thirteen elite wheat varieties were collected from the Wheat Research Centre of the Bangladesh Institute of Agricultural Research, Gazipur (Table 1). Two separate experiments were conducted during rabi season (November to February) of 2012 - 2013 in Bangladesh. Experiment 1 was conducted with 8 selected varieties out of 13 . Seeds of the selected varieties were placed for germination on 26 November 2012. Experiment 2 was started one month later from 26 December 2012. Seeds were germinated in clean tap water floated in foam net inside the plastic trays in both experiments (Fig. 1a). Around 200 seeds were germinated per tray for each variety in order to select 15 healthy seedlings with synchronized leaf appearance at transplanting in hydroponic nutrient solution. Seed germination process took 3 to 4 days. Seedlings were transplanted in hydroponic solution following a completely randomized design with 15 and 10 replicates for each of the thirteen varieties in Experiment 1 and Experiment 2, respectively. There were 10 individual trays; each tray contained 13 individual plants, for setting up the whole experiment in both Experiment 1 ( 8 varieties $\times 15$ replicates) and Experiment 2 (13 varieties x 10 replicates). Each tray contained 13 plants, one from each variety. Thus a total of 120 and 130 individual plants were maintained in Experiment 1 and Experiment 2, respectively.Plants in each tray rotated their position randomly every week to avoid any position effect. Leaf appearance interval of all varieties was monitored for two weeks and that was calculated around 10 days $\left(90^{\circ} \mathrm{C}\right.$ days). Plants were fed with following nutrient solution: $1 \mathrm{mM} \mathrm{NH}_{4} \mathrm{NO}_{3}, 0.6 \mathrm{mM} \mathrm{NaH}_{2} \mathrm{PO}_{4} \cdot \mathrm{H}_{2} \mathrm{O}, 0.6 \mathrm{mM} \mathrm{MgCl} 2 . \mathrm{H}_{2} \mathrm{O}, 0.3 \mathrm{mM}$ $\mathrm{K}_{2} \mathrm{SO}_{4}, 0.3 \mathrm{mM} \mathrm{CaCl}_{2} \cdot \mathrm{H}_{2} \mathrm{O}, 50 \mu \mathrm{M} \mathrm{H}_{3} \mathrm{BO}_{3}, 90 \mu \mathrm{M}$ Fe-EDTA, $9 \mu \mathrm{M} \mathrm{MnSO}_{4} .4 \mathrm{H}_{2} \mathrm{O}, 0.7 \mu \mathrm{M} \mathrm{ZnSO} \mathrm{Z}_{4} .7 \mathrm{H}_{2} \mathrm{O}, 0.3 \mu \mathrm{M}$ $\mathrm{CuSO}_{4} .5 \mathrm{H}_{2} \mathrm{O}, 0.1 \mu \mathrm{M} \mathrm{NaMoO}{ }_{4} \cdot 2 \mathrm{H}_{2} \mathrm{O}$ dissolved in tap water. The nutrient solution was refreshed weekly. All plants were under similar management until the destructive harvest.

In Experiment 1, destructive harvests were carried out at three different time points: i) on 50 days after sowing (DAS), a subset data was recorded at phytomer level for 3 replicates only for the variety Shotabdi for the following traits: number of root bearing phytomers (youngest root bearing phytomer, $\operatorname{Pr} 1$, was the reference point (e.g., Yang et al., 1998) \& roots per phytomer; diameter and length of main axis, first order laterals, second order laterals and root hairs; densities of first \& second order laterals and root hairs at their axis of origin, ii) on 60 DAS, subset of data were recorded at phytomer level with 4 replicates for the two varieties: Shotabdi and Sonalika for the same root traits as likes as the first harvest, iii) on 66 DAS, data were recorded for 8 varieties with 5 replicates only for the root bearing phytomer position 5 (Pr5, youngest roots were the reference point and numbered as phytomer 1) for all root traits similar to the first harvest along with number of live leaves and adventitious roots per main tiller. 
Table 1. Description of the thirteen wheat varieties used for studying root growth and development hydroponically

\begin{tabular}{|c|c|c|c|c|c|c|}
\hline Variety & Year of release & $\begin{array}{l}\text { Plant } \\
\text { height }\end{array}$ & $\begin{array}{l}\text { Growth } \\
\text { duration } \\
\text { (days) }\end{array}$ & $\begin{array}{l}\text { Panicle } \\
\text { initiation/ } \\
\text { (days) }\end{array}$ & $\begin{array}{l}\text { Yield, } \\
\left(\mathrm{t} \mathrm{ha}^{-1}\right)\end{array}$ & Special characteristics \\
\hline Shotabdi & 2000 & $90-100$ & $105-112$ & $65-69$ & $3.6-5.0$ & Heat tolerant \\
\hline Shourov & 1998 & $90-100$ & $102-110$ & $60-67$ & $3.5-4.5$ & Leaf rust tolerant \\
\hline Sufi & 2005 & $90-102$ & $100-110$ & $58-62$ & $3.6-4.8$ & Leaf rust resistant, heat tolerant \\
\hline Prodeep & 2005 & $95-100$ & $102-110$ & $64-66$ & $3.5-51$ & $\begin{array}{l}\text { Leaf rust resistant, heat tolerant, good } \\
\text { baking quality }\end{array}$ \\
\hline Bijoy & 2005 & $95-105$ & $103-112$ & $60-65$ & $4.3-5.0$ & Heat tolerant \\
\hline BARI gom25 & 2010 & $95-100$ & $102-110$ & $57-61$ & $3.6-4.6$ & Salt tolerance $6-8 \mathrm{dS} \mathrm{cm}^{-1}$ \\
\hline BARI gom 26 & 2010 & $92-96$ & $104-110$ & $60-63$ & $3.5-4.5$ & Leaf rust resistant, leaf spot tolerant \\
\hline BARI gom $27^{1}$ & 2012 & $80-90$ & $105-110$ & $63-67$ & $3.5-5.4$ & $\begin{array}{l}\text { Moderately heat tolerant, saline prone }>8.0 \\
\mathrm{dSm}^{-1}\end{array}$ \\
\hline 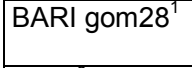 & 2012 & $80-90$ & 102-108 & $58-62$ & $4.0-5.5$ & $\begin{array}{l}\text { Moderately terminal heat tolerant, saline } \\
\text { prone }>8.0 \mathrm{dSm}^{-1}\end{array}$ \\
\hline Kheri $^{2}$ & Indigenous cultivar & 113 & 110-115 & 65-69 & $2.5-3.0$ & \\
\hline Sonalika $^{2}$ & & 92 & $100-110$ & $58-62$ & $30-3.5$ & \\
\hline Kanchan & 1983 & $90-100$ & $106-112$ & $60-68$ & $3.5-4.6$ & Leaf rust susceptible \\
\hline Akbar & 1983 & $85-90$ & $103-108$ & $50-55$ & $3.5-4.5$ & Leaf rust tolerant \\
\hline
\end{tabular}

Source: (Mondol et al., 2011), ${ }^{1}$ data collected from Wheat Research Centre of Bangladesh Agricultural Research Institute, ${ }^{2}$ collected by the authors from the field grown plants.

In Experiment 2, destructive harvests were carried out at two time points for all 13 varieties: the first one was on 40 DAS to record number of live leaves, adventitious roots, seminal roots, and dry weights of roots and shoots of the main tiller from 5 replicates. The second harvest was carried out on 57 DAS to record data on number of new roots formed at the Pr1, root bearing phytomer, adventitious roots, seminal roots, main axis length at Pr1-Pr4, maximum primary axis length at Pr3, root hair density with the diameter of the axis of origin, root hair length and diameter, root and shoot dry weights etc. All data were recorded for the main tiller only, with 3 replicates.
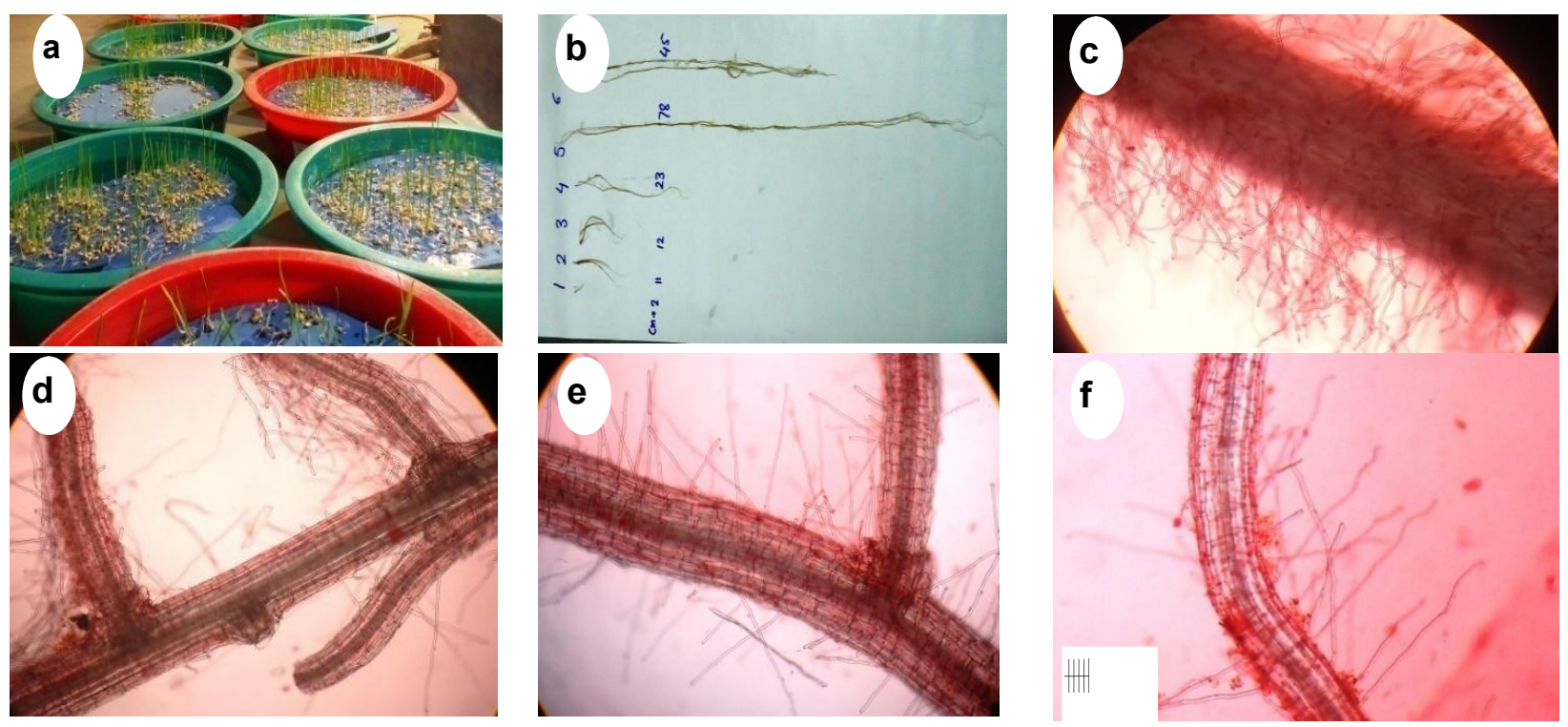

Fig. 1. Experimentation with the variable root traits of wheat at the phytomer level. a) Germination process of wheat seeds in tap water, b) Main axes collected from six different root bearing phytomers of wheat variety Shotabdi, c) numerous root hairs originated from a main axis of Shotabdi, d) a first order lateral with three second order laterals and root hairs of Sonalika, e) a primary branch with root hairs of Sonalika and f) a secondary branch of BARI gom 27 with root hairs. Root hair density and other measurements were carried out at 100x magnification. One small division at $100 \mathrm{x}$ is equivalent to $10 \mu$. 
Diameter of the main axis, root hair density, length and diameter of root hair were measured at $100 \mathrm{x}$ magnifications under a light microscope (Fig. 1). Safranin solution of $0.5 \%$ prepared in $50 \%$ alcohol was used for staining root hairs. Main axis elongation rate between Pr1 and Pr2 was measured from length gain at Pr2 from Pr1 per day (using data for phyllochron per day).

Data were analyzed using MINITAB 15 statistical software package to find out variations: i) among successively more developed phytomer of the same variety, Shotabdi, at the first harvest of Experiment 1 for different root treatments measured, ii) variation between two harvests, 50 DAS versus 60 DAS, of the same variety in the Experiment 1, iii) variations between two varieties, Shotabdi versus Sonalika, on 60 DAS for root development at phytomer level in Experiment 1, iv) variations among 8 varieties in Experiment 1 on 66 DAS, v) variations among 13 varieties on 40 and 57 DAS for the measured variables in Experiment 2. Analysis of variance was conducted using general linear model command. Principal component analysis,for the data obtained in Experiment 2, was carried for the selected traits, based on genotypic variations for root traits, of both experiments to find out the varietal differences associated with root traits.

\section{Results}

\section{Experiment 1}

Root hair diameter varied significantly among phytomer position (Fig. 2). Root hairs developed at $\operatorname{Pr} 1$ and Pr2 were greater in diameter than those originated from first and second order laterals measured at Pr3-4 and Pr5, respectively (Fig.1 \& 2). Diameter of the root hairs had significant correlation with their axis of origin (Fig.1 \& 2, r = 0.515, p = 0.002). Main axis length increased from Pr1 towards Pr5 for Shotabdi, measured on 50 and 60 DAS (Fig. 1b \& 3a) and also for Shotabdi and Sonalika, measured on 60 DAS (Fig. 3b). Root hair density was initially recorded in per $\mathrm{mm}$ root length, decreased marginally from younger towards the older phytomer positions (Fig. 4, $p=0.09$ ). As root hairs were not always measured at the similar axis of origin, e.g., either at main axis or at first order of laterals, therefore the density was converted to per $\mathrm{mm}^{2}$ surface area (Fig. 4). Root hair densities in per $\mathrm{mm}^{2}$ surface area were much higher at the main axes of Pr1-2 compared to that in per mm length (Fig.4).

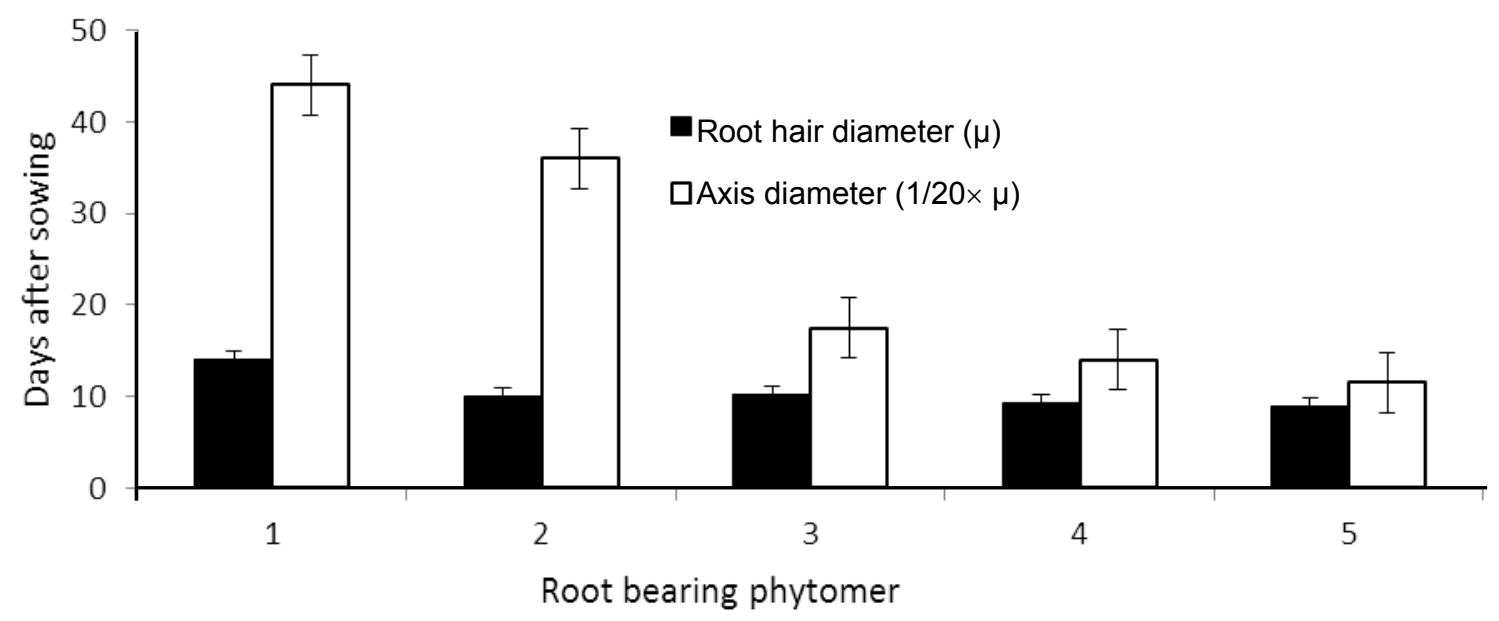

Fig. 2. Diameter of the root hairs (black bars) and their axis of origin (white bars) of wheat variety Shotabdin Experiment 1 on 50 DAS at different root bearing phytomers. The axis of origin for root baring phytomer (Pr) 1-2 refers main axis and those for $\operatorname{Pr} 3-5$ refers first order laterals. Vertical bars indicate standard error mean. $P$ values are 0.001 for black bars and $<0.001$ for white bars. 


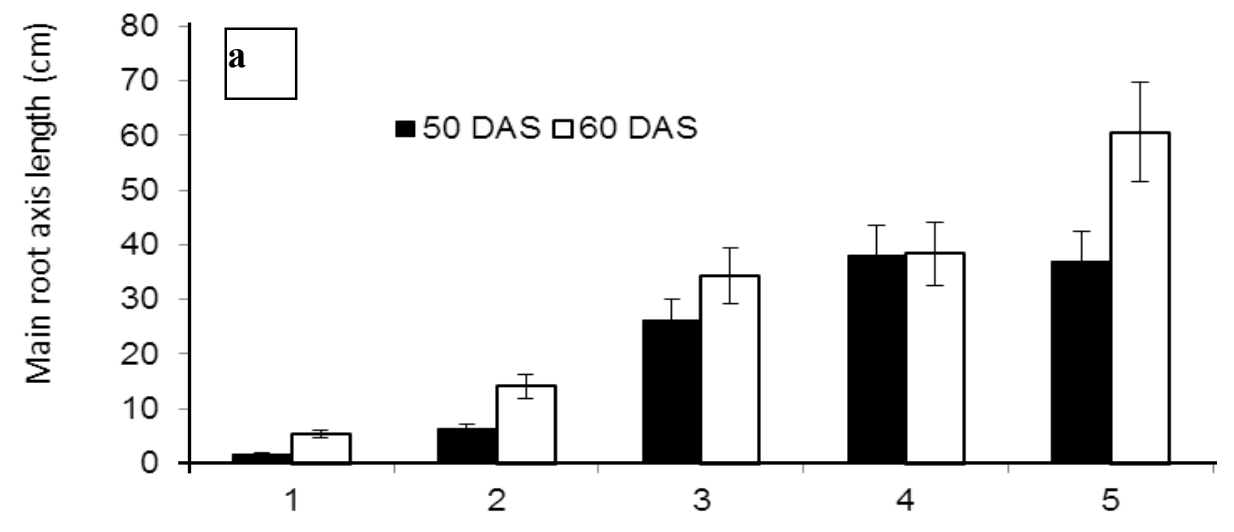

Root bearing phytomer

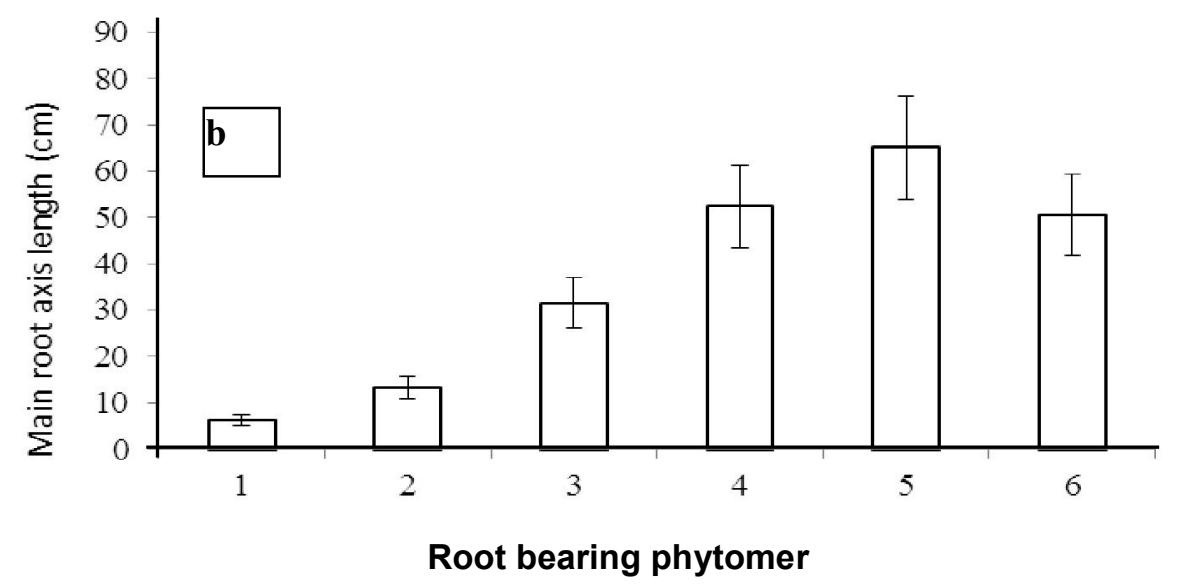

Fig. 3. Main axis length at different root bearing phytomer position of wheat in Experiment 1 for: a) variety Shotabdi on 50 and 60 DAS and b) two varieties Shotabdi and Sonalikaon 60 DAS. Vertical bars show back-transformed standard error of means in \% of the log-transformed data. $P<0.001$

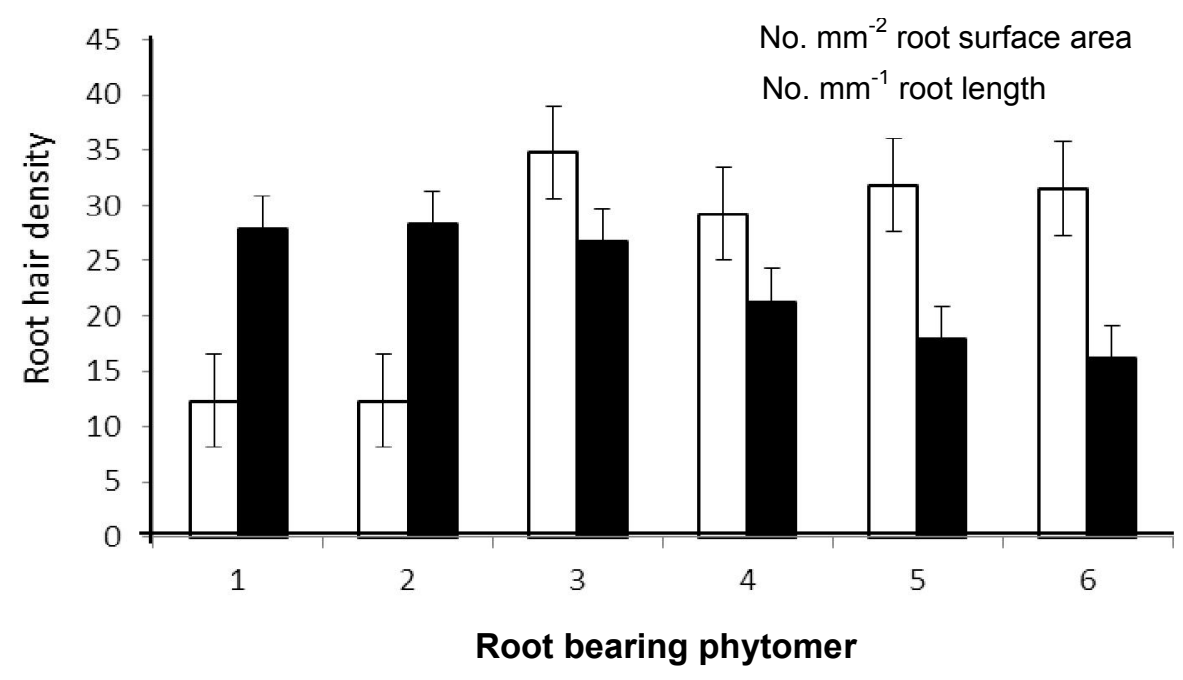

Fig. 4. Root hair density at different phytomer position ( $\mathrm{Pr}$ ) of Shotabdi and Sonalika in Experiment 1 accounted for 1 $\mathrm{mm}$ root length (black bars) and estimated for per $\mathrm{mm}^{2}$ surface area (white bars) of main axis for Pr1-2, first order laterals Pr3-5 and second order laterals $\operatorname{Pr} 6$. Vertical bars indicate standard error mean. P value is 0.001 for both white and black bars 
Densities of the first order laterals originated per $\mathrm{mm}$ main axis were significantly different among varieties (Table 2, $p=0.027$ ). BARI gom 27 accounted for the highest number of first order laterals per $\mathrm{mm}$ main axis (Table 2). Similar to density of first order laterals, dry weights of roots and shoots of the main tiller were also significantly differed among 8 varieties in Experiment 1 (Table 2). The variety Shourov accounted for the highest root and shoot dry weights followed by BARI gom28 (Table 2). Even though both root and shoot dry weights differed significantly among varieties but the variation for root:shoot ratio was marginal (Table 2). Unlike both root and shoot dry weights, Sonalika accounted for the highest root:shoot ratio (Table 3).

Table 2. Density of first order laterals at the axis of origin, dry weights of roots and shoots and root:shoot ratio of 8 wheat varieties in Experiment 1. SEM, standard error or mean; $\mathbf{P}$, probability of statistical significance

\begin{tabular}{|l|c|c|c|c|}
\hline Variety & $\begin{array}{c}\text { Density of first order laterals } \\
\text { (no. per mm main axis) }\end{array}$ & $\begin{array}{c}\text { Root dry } \\
\text { weight }(\mathrm{g})\end{array}$ & $\begin{array}{c}\text { Shoot dry } \\
\text { weight }(\mathrm{g})\end{array}$ & $\begin{array}{c}\text { Root:shoot } \\
\text { ratio }\end{array}$ \\
\hline Shotabdi & 4.8 & 0.22 & 0.80 & 0.29 \\
\hline Shourov & 4.0 & 0.42 & 0.98 & 0.43 \\
\hline BARI gom25 & 4.8 & 0.29 & 0.83 & 0.34 \\
\hline BARI gom27 & 5.8 & 0.20 & 0.61 & 0.34 \\
\hline BARI gom28 & 4.0 & 0.40 & 0.92 & 0.45 \\
\hline Sonalika & 4.8 & 0.24 & 0.47 & 0.51 \\
\hline Kanchan & 4.6 & 0.31 & 0.69 & 0.44 \\
\hline Akbar & 5.0 & 0.29 & 0.72 & 0.38 \\
\hline SEM & 0.8 & 0.051 & 0.09 & 0.05 \\
\hline P value & 0.027 & 0.04 & 0.013 & 0.06 \\
\hline
\end{tabular}

Table 3. Morphological description of root and shoot traits of 13 wheat varieties on 40 DAS in Experiment 2. SEM, standard error or mean; P, probability of statistical significance

\begin{tabular}{|l|c|c|c|c|}
\hline Variety & $\begin{array}{c}\text { No. of adventitious } \\
\text { roots }\end{array}$ & $\begin{array}{c}\text { Root dry weight } \\
(\mathrm{mg})\end{array}$ & $\begin{array}{c}\text { Shoot dry weight } \\
(\mathrm{mg})\end{array}$ & $\begin{array}{c}\text { Root:shoot } \\
\text { ratio }\end{array}$ \\
\hline Shotabdi & 7.2 & 38 & 136 & 0.29 \\
\hline Shourov & 9.4 & 54 & 128 & 0.41 \\
\hline Sufi & 9.0 & 48 & 168 & 0.27 \\
\hline Prodeep & 12.0 & 76 & 170 & 0.47 \\
\hline Bijoy & 10.2 & 52 & 188 & 0.29 \\
\hline BARI gom25 & 9.4 & 58 & 126 & 0.46 \\
\hline BARI gom26 & 7.6 & 60 & 118 & 0.51 \\
\hline BARI gom27 & 9.4 & 56 & 124 & 0.45 \\
\hline BARI gom28 & 6.6 & 28 & 136 & 0.21 \\
\hline Kheri & 6.6 & 26 & 100 & 0.26 \\
\hline Sonalika & 8.6 & 66 & 168 & 0.39 \\
\hline Kanchan & 8.0 & 40 & 108 & 0.36 \\
\hline Akbar & 6.0 & 50 & 150 & 0.37 \\
\hline SEM & 0.79 & 8.23 & 16.0 & 0.045 \\
\hline P value & $<0.001$ & 0.003 & 0.006 & $<0.001$ \\
\hline
\end{tabular}




\section{Experiment 2}

As it was reflected by the PC1 scores in Experiment 1 for varietal difference number of adventitious roots per plant was significantly different among 13 varieties in Experiment 2 both on 40 DAS (Table 3) and 57 DAS (Table 4). As like as Experiment 1, dry weights of roots and shoot and root:shoot ratio were also significantly differed among 13 varieties in Experiment 2 (Table 3). Root:shoot ratio was non-significant on 57 DAS for the same varieties, even though dry weights for both roots and shoots remained significant (Table 4). As PC1 in Experiment 1 signaled, main axis length at Pr1 and Pr2 differed significantly and length of first order laterals at $\mathrm{Pr} 3$ and root hair density per $\mathrm{mm}^{2}$ surface area differed marginally among 13 varieties in Experiment 2 (Table 4). Number of root bearing phytomers was also differed highly significantly among 13 varieties as this trait was also appeared to show a significant contrast among 8 varieties in Experiment 1 (Table 4). Number of new roots appearance at Pr1 between 50 and 57 DAS had also significant variations for varieties (Table 4). Although number of live leaves did not produce any significant difference among varieties in Experiment 1 and on 40 DAS in Experiment 2, but showed significant variations on 57 DAS (Table 4). Other measured variables including main axis length at Pr4 \& $\operatorname{Pr} 5$, main axis elongation rate between $\operatorname{Pr} 1$ and $\mathrm{Pr} 2$, root hair diameter and length ranged from 12.3 to $40.7 \mathrm{~cm}, 16.3$ to $53.5 \mathrm{~cm}, 0.78$ to $3.3 \mathrm{~cm}$ per day, 9 to $11 \mu$ and 767 to $1300 \mu$, respectively, were nonsignificant for 13 varieties. PCA shows that PC1 and PC2 accounted for 42.4 and $14.2 \%$ data variation, respectively and both of the PC components resulted in significant variation among varieties for their respective PC scores (Table 5). PC1 had significant contrast for number of live leaves; new roots appeared between 50 and 57 days, root bearing phyotmer, total adventitious roots and dry weights of roots and shoots for their negative co-efficient values for all of these traits (Table 5). That means, this PC separates varieties according to the 'plant size'. PC2 separates varieties significantly with positive coefficients for number of live leaves, main axis length at Pr1 \& Pr2, root hair diameter and negative coefficients for new roots appeared between 50 and 57 days and root hair density (Table 5).

Table 4. Morphological description of root and shoot traits of 13 wheat varieties on 57 DAS in Experiment 2.Pr, root bearing phytomer position; SEM, standard error or mean; $P$, probability of statistical significance

\begin{tabular}{|l|c|c|c|c|c|c|c|c|c|c|}
\hline Variety & $\begin{array}{c}\text { Live } \\
\text { leaves }\end{array}$ & $\begin{array}{c}\text { No. of } \\
\text { new } \\
\text { roots }\end{array}$ & $\begin{array}{c}\text { No. of root } \\
\text { bearing } \\
\text { phytomer }\end{array}$ & $\begin{array}{c}\text { No. of } \\
\text { adventitious } \\
\text { roots }\end{array}$ & $\begin{array}{c}\text { Main axis } \\
\text { length at } \\
\text { Pr1 }\end{array}$ & $\begin{array}{c}\text { Main axis } \\
\text { length at } \\
\text { Pr2 }\end{array}$ & $\begin{array}{c}\text { Primary } \\
\text { branch length } \\
\text { at Pr3 }\end{array}$ & $\begin{array}{c}\text { Root hair } \\
\text { density } \\
\text { (no. mm-2) }\end{array}$ & $\begin{array}{c}\text { Root dry } \\
\text { weight } \\
\text { (mg) }\end{array}$ & $\begin{array}{c}\text { Shoot dry } \\
\text { weight } \\
\text { (mg) }\end{array}$ \\
\hline Shotabdi & 2.7 & 1.0 & 4.3 & 9.0 & 11.7 & 27.8 & 2.33 & 16.5 & 20 & 180 \\
\hline Shourov & 3.0 & 1.3 & 5.0 & 12.7 & 28.7 & 40.3 & 5.67 & 16.6 & 80 & 260 \\
\hline Sufi & 2.3 & 0.7 & 4.0 & 8.0 & 12.7 & 15.0 & 3.17 & 11.9 & 40 & 180 \\
\hline Prodeep & 5.3 & 5.3 & 7.0 & 17.7 & 5.5 & 15.8 & 1.50 & 27.1 & 160 & 490 \\
\hline Bijoy & 3.0 & 2.0 & 4.7 & 9.0 & 5.7 & 11.3 & 5.17 & 20.7 & 50 & 230 \\
\hline BARI gom25 & 3.3 & 2.0 & 5.7 & 12.7 & 6.0 & 20.7 & 3.83 & 22.1 & 70 & 220 \\
\hline BARI gom26 & 2.3 & 3.3 & 4.3 & 10.0 & 3.0 & 10.8 & 4.00 & 26.9 & 50 & 170 \\
\hline BARI gom27 & 2.3 & 2.0 & 4.3 & 10.0 & 9.5 & 24.5 & 5.83 & 35.0 & 40 & 200 \\
\hline BARI gom28 & 2.0 & 1.3 & 5.3 & 10.0 & 8.7 & 41.7 & 2.50 & 22.9 & 50 & 280 \\
\hline Kheri & 3.0 & 0.0 & 4.7 & 8.3 & 26.8 & 47.3 & 6.33 & 15.3 & 40 & 170 \\
\hline Sonalika & 2.0 & 1.3 & 4.0 & 8.3 & 16.7 & 36.3 & 4.00 & 15.7 & 30 & 150 \\
\hline Kanchan & 2.7 & 1.0 & 4.7 & 9.3 & 10.3 & 37.3 & 6.00 & 12.0 & 50 & 280 \\
\hline Akbar & 2.0 & 1.0 & 4.7 & 9.7 & 10.5 & 34.0 & 4.33 & 28.5 & 60 & 320 \\
\hline SEM & 0.49 & 0.64 & 0.36 & 1.44 & 5.15 & 7.22 & 1.08 & 1.6 & 17 & 52 \\
\hline P value & 0.003 & 0.001 & $<0.001$ & 0.005 & 0.035 & 0.01 & 0.067 & 0.087 & 0.001 & 0.007 \\
\hline
\end{tabular}


Table 5. Major principal components (PC) and their coefficients from principal component analysis of the root traits at the phytomer level along with shoot traits for 13 wheat varieties on 57 days after sowing. Pr, root bearing phytomer; $p$, probability of statistical significance of the PC (principal component) scores among varieties

\begin{tabular}{|l|c|c|}
\hline Traits & PC1 & PC2 \\
\hline Number of live leaves & -0.34 & 0.34 \\
\hline Number of new roots formed between 50 and 57 DAS & -0.38 & -0.31 \\
\hline Number of root bearing phytomers & -0.40 & 0.18 \\
\hline Total number of adventitious roots & -0.42 & 0.07 \\
\hline Main axis length at Pr1 & 0.14 & 0.40 \\
\hline Main axis length at Pr2 & 0.13 & 0.50 \\
\hline Root hair density & -0.17 & -0.47 \\
\hline Root hair diameter & 0.06 & 0.21 \\
\hline Root hair length & -0.11 & -0.14 \\
\hline Shoot dry weight & -0.38 & 0.18 \\
\hline Root dry weight & -0.42 & 0.16 \\
\hline \% variation explained & 42 & 14 \\
\hline P value (variety) & $<0.001$ & 0.009 \\
\hline
\end{tabular}

\section{Discussion}

\section{Phytomer difference}

A shorter main axis length at Pr6 compared to Pr5 suggested that the root position perhaps achieved maximum possible axis length at Pr6 (Fig. 3b). The youngest root bearing phytomer receives most part of photoassimilate and that decreases gradually towards the older phytomer (Matthew and Kemball, 1997). Substrate supply usually diminishes below Pr6 in perennial ryegrass (Matthew and Kemball, 1997; Robin, 2011). Pr6 was developed at the very early stage, around 50 days before the day of destructive harvest when plant size was small. Root hair density was directly correlated with surface area of axis of origin (Fig. 4, $r=0.365, p=0.014$ ) suggesting that the more the epidermal cells available the higher the chance of root hair formation.

\section{Varietal difference}

Main axis length at Pr1 and Pr2 brought significant difference among 13 wheat varieties (Table 4) but at Pr3 and Pr4 that difference was not significant (data not presented). It is important to note couple of issues in comparing main axis length among varieties: i) main axis elongated at the Pr1 and Pr2 at a faster rate compared to the older root bearing phytomers (Robin, 2011), ii) main axisfor a particular $\operatorname{Pr}$ at different replicates of same variety and different varieties did not appear at the same day, iii) destructive harvest process took 3-5 days across two experiments. Therefore in any further experimentation main axis elongation rate might be accounted in thermal time in rhizochron (root appearance interval) time scale for more validity. Significant difference in main axis elongation rate suggests that estimating main axis elongation would be regarded as an important selection criterion. PC2 indicated that main axis length at $\operatorname{Pr} 1$ and $\operatorname{Pr} 2$ is positively associated with number of live leaves present in main tiller (Table 5). Root growth and root elongation rate were also significantly different in some previous studies (see O'Toole and Bland, 1987; Shahzad et al., 2012). First order lateralsgenerally initiate at the Pr2 or Pr3 (Robin, 2011). Significant variation in length of first order lateralsat $\operatorname{Pr} 3$ suggestedthat at $\operatorname{Pr} 3$ thelaterals were at active elongation process, the same happens for main axis at Pr1 and Pr2.

PC1 showed that new root formation, number of root bearing phytomers, total number of adventitious roots per plant, and dry weights of roots and shoot are closely associated and hence directly dependent to number of live leaves per plant (Table 5, Robin, 2011). Dry weights of roots and shoots were consistently different among varieties across the experiments (Table $2 \& 4$, Chen et al., 2005; Yumurtaci 
and Uncuoglu, 2012). The results suggested these two traits should be alwaysregarded as selection parameters. Root hair density was marginally different among 13 wheat varieties in Experiment 2 (Table 4) suggesting that this trait is important to consideras previous reports also indicated that under various stress condition root hair density was variable; e.g., Haling et al. (2010) under acidic and alkaline condition and Shabala et al. (2003) under various $\mathrm{Na} / \mathrm{Ca}$ ionic ratios.

\section{Conclusion}

Based on the results of the two experiments the following root traits can be recommended for future breeding program: i) main axis length at the youngest 2-3 root bearing phytomer, ii) density and diameter of the root hairs along with root dry weight and shoot dry weight of the main tillers as all those traits were consistently significant across two experiments. The data can be also used for physiological growth modeling of roots, e.g., C budgeting of the wheat plants towards root construction.

\section{Acknowledgments}

This research was supported by the Bangladesh Agricultural University Research System (BAURES Grant No. 2012/09/AUGC). The authors acknowledge Dr. Cory Matthew and Dr. GHM Sagor for their comments on this manuscript.

\section{Author contributions}

AHKR planned and designed experiments; analyzed data and written the manuscript. MJU, SA and PRP assisted AHKR managing plants and data collection.

\section{References}

Bengough, A.G., Bransby, M.F., Hans, J., McKenna, S.J., Roberts, T.J., Valentine, T.A. 2006, Root responses to soil physical conditions; growth dynamics from field to cell. Journal of Experimental Botany 57:437-447.

Chen, Z., Newman I., Zhou, M., Mendham, N., Zhang, G., Shabala, S. 2005. Screening plants for salt tolerance by measuring K+ flux: a case study for barley. Plant, Cell \& Environment 28:1230-1246.

Crush, J., Easton, H., Waller, J., Hume, D., Faville, M. 2007. Genotypic variation in patterns of root distribution, nitrate interception and response to moisture stress of a perennial ryegrass (Lolium perenne L.) mapping population. Grass and Forage Science 62:265-273.

Ehdaie, B., Layne, A.P., Waines J.G. 2012. Root system plasticity to drought influences grain yield in bread wheat. Euphytica 186:219-232.

Haling, R.E., Richardson, A.E., Culvenor, R.A., Lambers, H., Simpson, R.J. 2010. Root morphology, root-hair development and rhizosheath formation on perennial grass seedlings is influenced by soil acidity. Plant and Soil 335:457-468.

Hebbar, K., Rane, J., Ramana, S., Panwar, N., Ajay, S., Rao, A.S., Prasad, P. 2014. Natural variation in the regulation of leaf senescence and relation to $\mathrm{N}$ and root traits in wheat. Plant and Soil:1-14.

Hurd, E. 1968. Growth of roots of seven varieties of spring wheat at high and low moisture levels. Agronomy Journal 60:201-205.

Hurd, E. 1974. Phenotype and drought tolerance in wheat. Agricultural Meteorology 14:39-55.

Lynch, J. 1995. Root architecture and plant productivity. Plant Physiology 109:7 - 13.

Maggio, A., Hasegawa, P.M., Bressan, R.A., Consiglio, M.F., Joly, R.J. 2001. Review: Unravelling the functional relationship between root anatomy and stress tolerance. Functional Plant Biology 28:999-1004.

Manschadi, A.M., Christopher, J., Hammer, G.L. 2006. The role of root architectural traits in adaptation of wheat to water-limited environments. Functional Plant Biology 33:823-837.

Manschadi, A.M., Hammer, G.L., Christopher, J.T. 2008. Genotypic variation in seedling root architectural traits and implications for drought adaptation in wheat (Triticum aestivum L.). Plant and Soil 303:115-129.

Matthew, C., Kemball, W. 1997. Allocation of carbon-14 to roots of different ages in perennial ryegrass (Lolium perenne L.), GRASSLAND CONGRESS. pp. 7.

Mondol, et al. 2011. KRISHI PROJUKTI HATBOI (Handbook on Agro-technology), $5^{\text {th }}$ edition, Bangladesh Agricultural ResearchInstitute, Gazipur 1701, Bangladesh. .

O'Brien, L. 1979. Genetic variability of root growth in wheat (Triticum aestivum L.). Crop and Pasture Science 30:587-595. 
O’Toole, J., Bland, W. 1987. Genotypic variation in crop plant root systems. Adv. Agron 41:91-145.

Richards, R., Passioura, J. 1989. A breeding program to reduce the diameter of the major xylem vessel in the seminal roots of wheat and its effect on grain yield in rain-fed environments. Crop and Pasture Science 40:943-950.

Robin, A.H.K. 2011. Segmental morphology of perennial ryegrass (Lolium perenne L.): a study of functional implications of plant architecture: a thesis presented in partial fulfilment of the requirements for the degree of Doctor of Philosophy in Plant Science, Institute of Natural Resources, College of Sciences, Massey University, Palmerston North, New Zealand.

Robin, A.H.K., Matthew, C., Crush, J. 2010. Time course of root initiation and development in perennial ryegrass-a new perspective. Proceedings of New Zealand Grassland Association 72:233-239.

Saqib, M., Akhtar, J., Qureshi, R. 2005. Na+ exclusion and salt resistance of wheat (Triticum aestivum) in saline-waterlogged conditions are improved by the development of adventitious nodal roots and cortical root aerenchyma. Plant Science 169:125-130.

Shabala, S., Shabala, L., Van Volkenburgh, E. 2003. Effect of calcium on root development and root ion fluxes in salinised barley seedlings. Functional Plant Biology 30:507-514.

Shahzad, A., Ahmad, M., Iqbal, M., Ahmed, I., Ali, G. 2012. Evaluation of wheat landrace genotypes for salinity tolerance at vegetative stage by using morphological and molecular markers. Genetics and Molecular Research 11:679-692.

Whalley, W., Dodd, I., Watts, C., Webster, C., Phillips, A., Andralojc, J., White, R., Davies, W., Parry, M. 2013. Genotypic variation in the ability of wheat roots to penetrate wax layers. Plant and Soil 364:171-179.

Yang, J., Matthew, C., Rowland, R. 1998. Tiller axis observations for perennial ryegrass (Lolium perenne) and tall fescue (Festuca arundinacea): number of active phytomers, probability of tiller appearance, and frequency of root appearance per phytomer for three cutting heights. New Zealand journal of agricultural research 41:11-17.

Yumurtaci, A., Uncuoglu, A. 2012. Tissue specific responses alter the biomass accumulation in wheat under gradual and sudden salt stress. Journal of Stress Physiology \& Biochemistry 8:143-156. 